\title{
A Forty Year Old Lady with Undiagnosed Lutembacher Syndrome - A Case Report
}

\author{
Muhammad Ashiqur Rahman 1, AKM.Fazlur Rahman², Tauhidul Haque1, Sajal K Banarjee², \\ Md. Harisul Hoque ${ }^{2}$, Md. Ashraf Uddin Sultan ${ }^{2}$

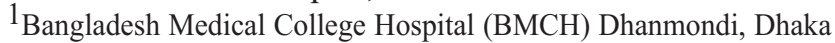 \\ ${ }^{2}$ Department of Cardiology, Bangabandhu Sheikh Mujib Medical University (BSMMU).
}

Address for Correspondence

Dr. Md.Ashiqur Rahman, Consultant Cardiology, Bangladesh Medical College Hospital, Dhanmondi, Dhaka.

e-mail : docashiq@bol-online.com

\begin{abstract}
A forty years widow having four children presented with palpitation, shortness of breath on exertion and chest pain. Her sufferings progressively increase in course of time. Her ECG shows complete Right Bundle Branch Block. Transthoracic echocardiography showed atrial septal defect of secundum type. Both the leaflets of the mitral valve were thickened with mild degree of diastolic doming.
\end{abstract}

Key Words : Lutembacher Syndrome, Mitral Stenosis.

\section{Introduction}

Mitral Stenosis, usually rheumatic in association with Atrial Septal Defect is called Lutembacher Syndrome. ${ }^{1}$ Lutembacher Syndrome is a very rare form of angiopathy. ${ }^{2}$ In Lutembacher Syndrome Mitral Stenosis is almost invariably the result of acquired Rheumatic valvulities. ${ }^{3}$ Since it's discovery the definition of Lutembacher Syndrome has undergone many changes. ${ }^{4}$ The mention of this syndrome was at first found in a letter written by an Anatomist Johan Friedmich Meckel to Albrencht Von Halley in 1750. Rene Lutembacher himself described this syndrome, in 1916, involving a 61 years old lady who had congenital Mitral Stenosis. Because the Mitral Stenosis was, in fact Rheumatic in origin so, the syndrome was defined eventually as a combination of congenital ASD and an acquired, Mitral Stenosis. However, in the setting of Mitral valvoplasty for acquired mitral stenosis where residual iatrogenous transseptal puncture is more common than congenital ASD, as is the combination of ASD and MS. Although this syndrome is generally defined as Mitral Stenosis in combination with ASD. Some define the syndrome as a combination ASD and any Mitral lesion i.e Mitral Stenosis or mixed lesion. Currently any combination of ASD, congenital or iatrogenic and Mitral Stenosis, acquired or congenital is referred as Lutembacher Syndrome.

\section{Case Report}

Mrs. Lithia Marandi, a mother of four children, who is a forty year old widow, hailing from Rajshahi, visited Bangladesh Medical College Hospital. She presented to us with palpitation, shortness of breath on exertion which is progressive in nature. Generalized weakness and occasional vertigo feeling has also associated. She did not give any history of leg or joints swelling, haemoptysis or pink frothy cough. Any definite history suggestive of rheumatic fever could not be elicitated. Symptoms suggestive of pulmonary hypertension (like paroxysmal nocturnal dyspnoea, orthopnoea and haemospysis) were absent.

On general examination she appeared anxious, body built below average, with poor nutritional status, cooperative and decubitus was on choice. She was mildly anemic but jaundice, clubbing, koilonychias were absent. Her respiration rate was 16 beats per minute, temperature was normal and Blood pressure, Systolic $100 \mathrm{~mm}$ of $\mathrm{Hg}$, Diastolic $70 \mathrm{~mm}$ of $\mathrm{Hg}$. Her neck veins were not engorged and both thyroid gland and lymph nodes were not enlarged. There were neither any abnormal pigmentation nor any scar mark seen. Hair distribution was normal. Any deformity or bony tenderness and gynaecomastia were absent.

On precordial examination:- On inspection, Apex beat was seen in left $5^{\text {th }}$ intercostal space just medial to the left mid clavicular line.No other visible palsation could be seen.

On palpation, other than left parasternal lift no other thrill or palpable heart sound were felt. $1^{\text {st }}$ heart sound ( $\mathrm{S} 1$ ) was loud at Mitral area. Fixed splitting of the $2^{\text {nd }}$ heart sound was heard at Pulmonary area. A localized Ejection Systolic Murmur of grade III intensity was noted of the left parasternal border especially at the left $2^{\text {nd }}$ intercostal space.

Examination of other system revealed no other abnormalities. 


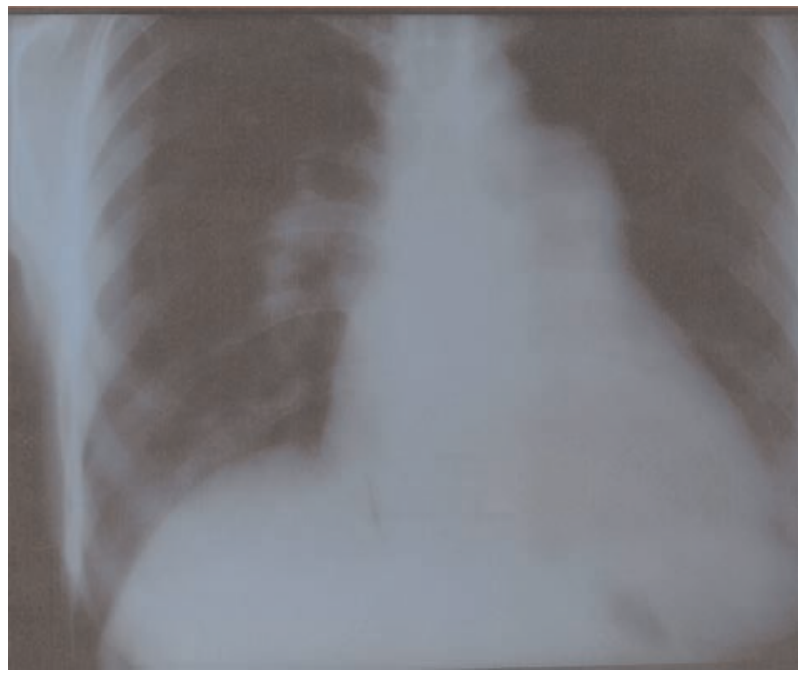

Fig 1 : X-Ray chest PA view of the patient

X-Ray chest PA view (Fig 1) shows cardiomegaly with right ventricular type of apex. There is straightening of the left border of the heart with fullness of the Pulmonary conus, Hilar Arteries were prominent with dilated upper lobe veins i.e upper lobe diversion was present, lung fields were plethoric and contained patchy opacities involving lower \& mid zones.

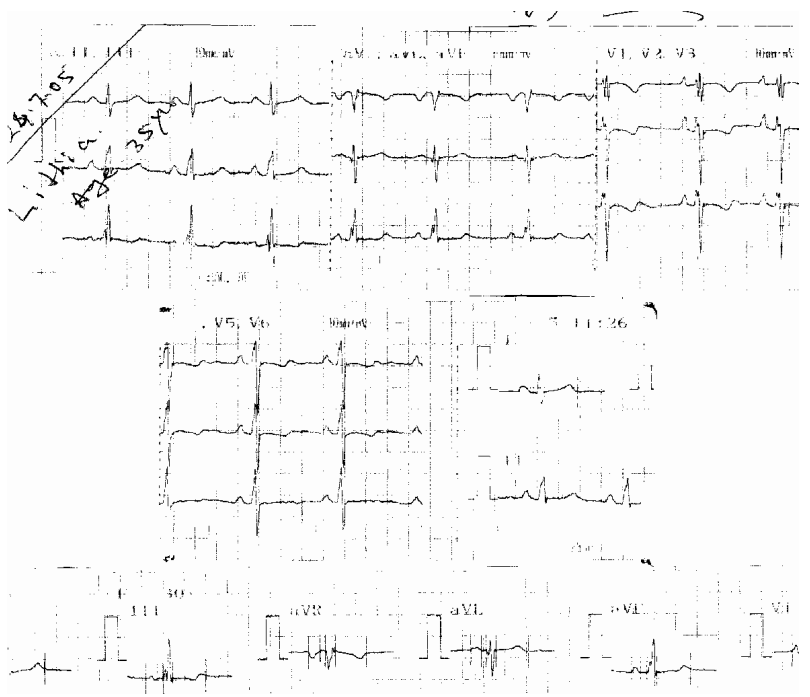

Fig 2: Electrocardiogramof the patient

Electrocardiogram (Fig 2) shows sinus rhythm with ventricular rate of 74 beats per minute. Broad $\mathrm{P}$ wave was noted in lead II indicating left Atrial enlargement. QRS morphology shows complete Right Bundle Branch Block (RBBB).

Transthoracic Echocrdiography (Fig 3) Both left parasternal long axis view and Apical view showed large Atrial Septal Defect of secundum type. Both the leaflet of the Mitral valve were thickened with mild degree of doming during diastole. Both right ventricle \& right atrium were dilated. Left ventricle was D shaped and compressed by dilated right ventricle. Interventricular septal movement was paradoxical. Pulmonary Artery appeared to be dilated. Left ventricular Ejection Fraction was $67 \%$.

Special emphasis should be given to Echocardiography evaluation of the Lutembacher Syndrome complex particularly at the setting of percuteneous Mitral Valvoplasty, which produce the Iatrogenic form of the Lutembacher Syndrome. ${ }^{5}$
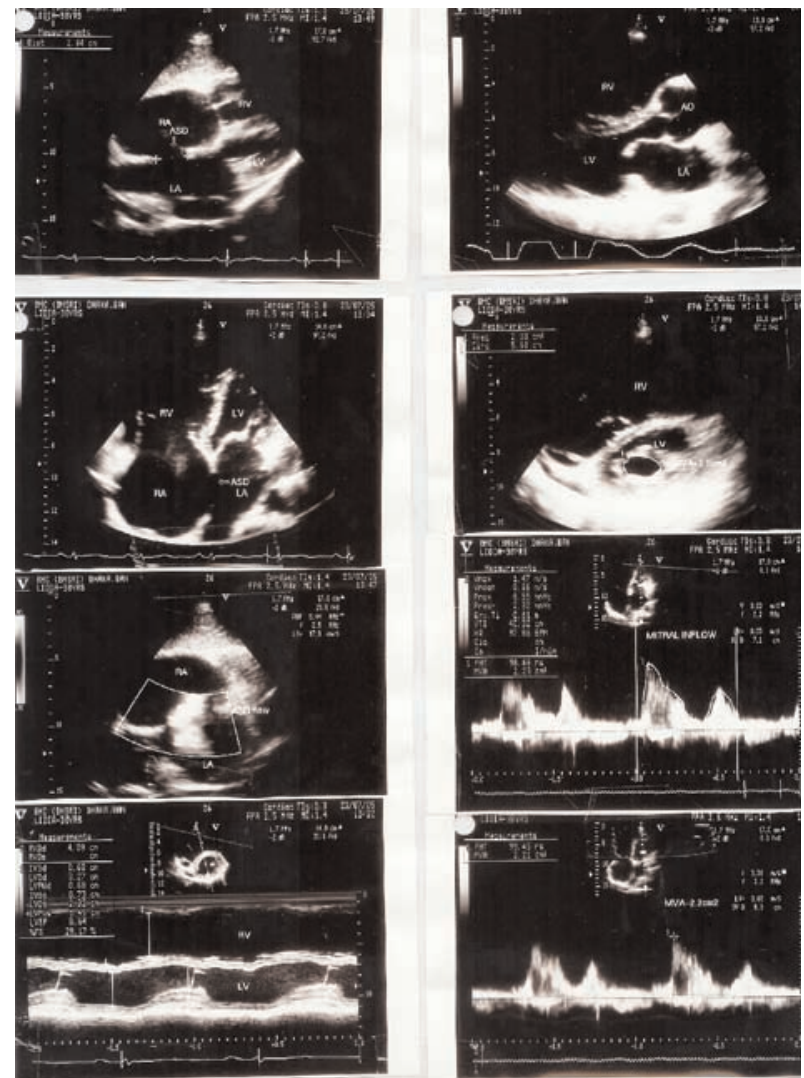

Fig 3: Ehcocardiography of the patient

Doppler Ehcocardiography (Fig 3) At Mitral Valve level Vmax was $1.5 \mathrm{~m} / \mathrm{sec}$, PPG $8.7 \mathrm{mmHg}$ and plenimetry of the Mitral valve area showed $2 \mathrm{~cm}^{2}$. reveals Pulmonary Velocity was $2.0 \mathrm{~m} / \mathrm{sec} \&$ Aortic velocity $1.5 \mathrm{~m} / \mathrm{sec}$. TR maximum $2.7 \mathrm{~m} / \mathrm{sec}$, PASP $39.6 \mathrm{mmHg}$. In colour flow imaging ASD flow was documented with left to right shunt with mild Tricuspid valve regurgitation. The Pressure half time method used most commonly for estimating MVA echocardiographiclly is inaccurate and may lead to underestimation of the severity of Mitral Stenosis in patient with Lutembacher Syndrome. ${ }^{6}$ So,a large ASD (Secundum) with left to right shunt, Doppler evidence of mild Pulmonary Hypertension, dilated Right Ventricle and Right Atrium were noted. Mild Mitral Stenosis, mild Tricuspid regurgitation with normal left ventricular function were also noted. Transoesophageal echocardiogram and Cardiac catheterization could not be done because of both financial problem and patient's noncooperation. 


\section{Discussion}

As a component of Lutembacher Syndrome Mitral Stenosis could be either congenital, as initially described, or it could be acquired iatrogenicly but commonly due to Rheumatic Mitral Valve disease. The true incidence rate of Lutembacher Syndrome is not available yet. The incidence of ASD in patients with Mitral Stenosis was thought to be 5 out of 2500 autopsies. This Syndrome could not be properly diagnosed in the past decades due to lack of Echocardiographic facility. The combination of mid diastolic murmur actually due to increased flow (relative stenosis) across the Tricuspid Valve and the Ejection Systolic Murmur of ASD leads to mistaken diagnosis of this syndrome. The incidence of Lutembacher Syndrome is high in countries where the prevalence of both Rheumatic Heart Disease and Mitral Stenosis are high. In Bangladesh there is no statistical data for Lutembacher Syndrome but Rheumatic Fever/Rheumatic Heart Disease (RF/RHD) is one of the most common cardiovascular problem existing among children and adolescents. Prevalence rate of RF/RHD was 4 per thousand in a selected population of 5 to 15 years of age group in Dhaka district including both rural and urban population. ${ }^{6}$ In another study on prevalence of RF/RHD in 5 to18 years old school children of Dhaka city revealed that the isolated Mitral Regurgitation was the commonest valvular lesion (38\%) followed by Mitral Stenosis and combined Mitral Stenosis and Mitral Regurgitation. ${ }^{7} \mathrm{~A}$ higher prevalence rate of $\mathrm{RF} / \mathrm{RHD}$ prevailed before the antibiotic era but as the frequency of RHD has changed, so the diagnosis of Lutembacher Syndrome has become significantly reduced. At the same time, the etiology of ASD as a component of Lutembacher Syndrome is either congenital or acquired (iatrogenic). Mitral Stenosis needs to high atrial pressure which stretch open the patent foramen Ovale causing left or right shunt thus provides another outlet for the left atrium. Haemodynamic effects of Lutembacher Syndrome depends on the extent of Mitral Stenosis. Even though Iatrogenic ASD is smaller in size but still haemodynamic direction of blood flow is determined by the Compliance of left and right Ventricles. Normally Right ventricle is more compliant than left ventricle. In the Lutembacher Syndrome due to the presence of Mitral Stenosis, blood flows to the right atrium through ASD without giving a backward pressure into the Pulomonary Veins. So, the Pulmonary Congestion does not take place as it occurs in case of pure Mitral Stenosis. But left to right shunting of blood through ASD leads to dilatation and ultimately failure of the Right Ventricle. Pulmonary Artery gets dilated and hypertrophy of the right ventricle occur in course of time. The diameter of the dilated pulmonary artery sometimes exceeds the diameter of the Thoracic Aorta. In very rare occasion the term Reverse Lutembacher Syndrome is used to describe the right to left shunt which may occur owing to the development of severe Tricuspid Stenosis. As a matter of fact that both congenital ASD and Rheumatic fever is more common in female. So, Lutembacher Syndrome is more frequently seen among female sexes.

Lutembacher Syndrome is usually treated surgically. ${ }^{8}$ By surgical procedure this condition is usally treated by Mitral valve operation and with concomitant closure of the Atrial Septal Defect. ${ }^{9}$ Surgery may be hazardous in some selective cases. In some instances of presence of small left ventricle surgery will lead to death. ${ }^{10}$ Transcatheter therapy is an effective alternative to surgery in selected patients with Lutembacher syndrome. ${ }^{11}$ In Transcatheter therapy, Percuteneous Transcatheter Mitral Commissurotomy using the Inoue balloon and closure of the Atrial Septal Defect with the Amplatz Atrial Septal defect occluder. Whenever patient with Pulmonary Hypertension with calcified Mitral valve leafleat then Percuteneous Transcatheter Mitral Commissurotomy and or surgery become contraindicated. As the patient is poor, so, the patient was managed by medical therapy alone.

\section{References}

1. Subadin H, Sarano M, Schaff H et.al: Mitral Valve Disease. Hursts the heart.2001;1697 (57)

2. Lutembacher R, De la stionose mitrale avec communication interauriculaire. Archives des maladies du coeur et des vaisseaux, Paris, 1916, 9 : 237-60

3. Bashi VV,Ravikwmar E,Jairaj PS et.al: Coexistent Mitral Valve disease with left to right shunt at the atrial level: clinical profile, haemodynamics and surgical considerations in 67 consecutive patients. Am Heart J 1987; 114: 1406

4. Rizj K:Lutembacher Syndrome,E medicine, instant access to the minds of medicine, http://www.emedicine.com/ med/topic 3424.htm

5. Ananthasutoramanium K, Iyer G, Karthikeyan V et.al: Giant left atrium secondary to Mitral stenosis leading to aequired lutembacher syndrome: a case report with emphasis on role of echocardiography in assessment of Lutembacher syndrome, Jam Soc Echocardiography, 2001; 14 (10) : 1033-35

6. Mahmud RS, Hossain M, Ahmed N, et.al : Prevalence of Rheumatic fever and Rheumatic heart disease in $5-18$ years age school children, chest and heart. Bulletin. 1992, 16(1) : $15-22$ 
7. Islam MN, Alimuzzaman M, Zafar A et.al : Organic tricuspid valve involvement in Rheumatic Mitral Valve disease. A two dimensional Echocardiography study. Bangladesh heart journal. 1987, 2 (2) : $82-88$

8. Ahmed WH, Al-shaibo KF, Chamsi-pasha H et.al:Non surgical correction of Lutembacher syndrome, Saudi Med J, 2003; 24 (3) : $307-08$

9. Chau EM, LeeCH, ChowWT: Transcatheter treatment of a case of Lutembacher Syndrome, Catheter Cardiovasc Interv.2000; 50 (1):68-70

10. Nazem N, Nazem A,Nazem S, : Suggested new approach in the treatment of Lutembacher Syndrome, with moderately hypoplastic left ventricle, Panminerva. Med.1997;39 (2):149-52

11. Joseph G, Abhaichand Rajpal K, Kumar KP: Definitive percutaneous treatment of Lutembacher's syndrome, Cathet Cardiovase Intervent 1999; 48 : 199 $-204$

12. Bari MA, Haque MS, Uddin et.al: Lutembacher's Syndrome, Mymensing Med J.2005.;14 (2) 